\title{
Danube Delta Tourism Resilience and Sustainability Test During COVID-19 Pandemic
}

\author{
Romeo Cătălin Crețu ${ }^{1}$, Raluca Florentina Crețu ${ }^{2}$ and Ioan Iulian Alecu ${ }^{3}$ \\ ${ }^{1) 3)}$ University of Agronomic Sciences and Veterinary Medicine of Bucharest, Bucharest, \\ Romania. \\ 2) The Bucharest University of Economic Studies, Bucharest, Romania. \\ E-mail: creturomeocatalin@yahoo.com; E-mail: raluca.cretu@cig.ase.ro \\ E-mail: iulian_alecu_2000@yahoo.com
}

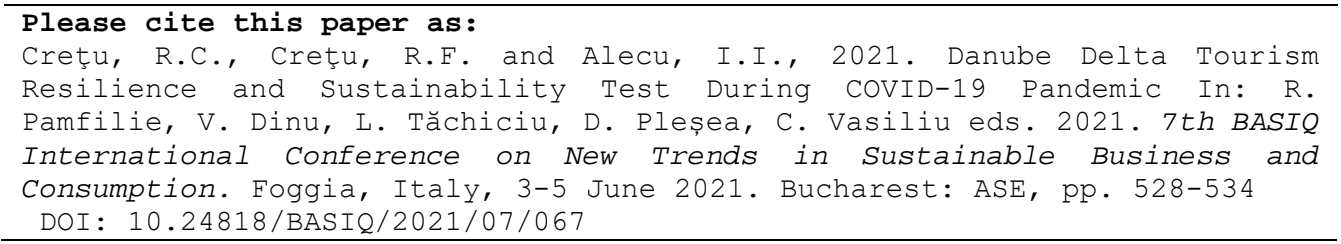

\begin{abstract}
World tourism faced the worst year ever in 2020, with the World Tourism Organization (UNWTO) announcing a $74 \%$ reduction in the number of international arrivals as a result of the COVID-19 pandemic. Destinations around the world last year saw a decrease of one billion in the number of international visitors, compared to a decline of only $4 \%$ during the economic crisis of 2009 . The HoReCa industry in Romania had in 2019 revenues of 5 billion euros, and in 2020 it lost about 3 billion euros, of which 1 billion is just the losses of hoteliers. This research focuses on two main aspects, each equally important for tourism actors. First, we analyzed the impact of the Covid-19 pandemic on tourism in the Danube Delta in 2020 and whether the resilience and sustainability test was passed. The second aim of the research was to identify solutions for the relaunch and development of tourism in the Danube Delta. Several research methods have been used to meet our objectives, such as analysis, synthesis, comparison, observation or documentary research. The quantitative research methodology used is limited to the questionnaire-based survey. The questionnaire contained 16 questions and was administered online between 10-25 March 2021. We had a number of 35 respondents, owners or administrators of classified accommodation units in the Danube Delta. The analysis of the results shows that the pandemic had a neutral to positive effect for tourism in the Danube Delta and that, for the most part, the resilience and sustainability test was passed. We consider that this study is very useful for tourism entrepreneurs, for local and central public authorities and the conclusions and recommendations extracted from the questionnaires can suggest valuable ideas for the relaunch and development of tourism in the Danube Delta.
\end{abstract}

\section{Keywords}

Danube Delta, tourism, resilience, sustainability, Covid-19, HoReCa industry.

DOI: $10.24818 /$ BASIQ/2021/07/067

\section{Introduction}

In 2019, travel and tourism were some of the most important sectors of the world economy, almost $10 \%$ of global GDP, with over 320 million jobs worldwide and a value of nine trillion dollars. In Europe, the tourism sector accounts for $10 \%$ of EU GDP (up to $25 \%$ in Croatia, $22 \%$ in Cyprus and $21 \%$ in Greece, if indirect impact is included) and generates, directly and indirectly, 23 million jobs. However, the COVID-19 pandemic puts the European tourism industry under unprecedented pressure: there has been a $60 \%$ to $90 \%$ drop in bookings over the same periods in previous years. 2020 was an atypical, difficult and unusual year, it changed the way we live, work and many of the values we thought were 
important (Brouder, 2020). Both human health and activity in all industries were mainly negatively affected by the coronavirus pandemic. The tourism industry was no exception, as it was one of the most affected by the dreaded virus and restrictions (Volkmann, et al., 2021). Destinations around the world last year saw a one billion drop in the number of international visitors, compared to a decline of only $4 \%$ during the global economic crisis of 2009. In Romania, the arrivals registered in the tourist reception structures in 2020 amounted to 6335.4 thousand, decreasing by $52.3 \%$ compared to 2019 . Of these, $92.8 \%$ represented the arrivals of Romanian tourists and $7.2 \%$ represented the arrivals of tourists foreigners. (Table no. 1). The arrivals of foreign tourists - from Europe $78.4 \%$ of the total foreign tourists, and of these $74.2 \%$ were from the E.U countries.

Table no. 1. Arrivals registered in the tourist reception structures in Romania 2019-2020

\begin{tabular}{|c|c|c|}
\hline $\begin{array}{c}\text { Tourist arrivals in Ro- } \\
\text { mania }\end{array}$ & 2020 & 2019 \\
\hline Romanian tourists & $5,879,251$ & $10,597,000$ \\
\hline Foreign tourists & 456,149 & $2,671,000$ \\
\hline TOTAL & $6,335,400$ & $13,268,000$ \\
\hline
\end{tabular}

Source: www.insse.ro

The overnight stays registered in the tourist reception structures in 2020 amounted to 14444.7 thousand, decreasing by $51.6 \%$ compared to those in 2019 (Table no. 2). Of these, 93.1\% represented the overnight stays of Romanian tourists and $6.9 \%$ the overnight stays of foreign tourists. The overnight stays of foreign tourists - from Europe $77.2 \%$ of the total foreign tourists, and $73 \%$ of them were from European Union countries.

Table no. 2. Overnight stays registered in the tourist reception structures in Romania 20192020

\begin{tabular}{|c|c|c|}
\hline $\begin{array}{c}\text { Overnight stays registered in the } \\
\text { tourist reception structures }\end{array}$ & 2020 & 2019 \\
\hline Romanian tourists & $13,448,015$ & $24,612,000$ \\
\hline Foreign tourists & 996,685 & $5,258,000$ \\
\hline TOTAL & $14,444,700$ & $29,870,000$ \\
\hline \multicolumn{2}{|c}{ Source: www.insse.ro } \\
\hline
\end{tabular}

The tourism industry in Tulcea County recorded, in 2020, losses of 17.55 million euros, in the context in which the number of those who visited the county was $29 \%$ lower than the previous year, due to the health crisis, according to data offered by the Danube Delta Tourist Destination Management Association (AMDTDD). Last year, 119,019 tourists arrived in the county, 29\% less than in 2019, when 168,412 tourists were registered, but more by about $15 \%$ than in 2018 , when the county was visited by 100,430 people. The biggest losses in the industry in the county were registered at the level of tourism with river cruise ships, given that over $95 \%$ of the ships scheduled to arrive in the county last year canceled their arrivals, due to the health crisis. Another cause was the cancellation of the festivals in the Danube Delta, which in previous years attracted many Romanian and foreign tourists. Certain sectors of the tourism industry may never be able to return to pre-crisis levels, in particular due to the digital transformation that was already under way and was accelerated by the situation (Sârbu, et al., 2020). An example is the MICE sector, where virtual meetings have shown that there is no need for international travel to attend conferences.

This research focuses on two main aspects, each equally important for tourism actors. First, we analyzed the impact of the Covid-19 pandemic on tourism in the Danube Delta in 2020 and whether the resilience and sustainability test was passed. The second aim of the research was to identify solutions for the relaunch and development of tourism in the Danube Delta.

We consider that this study is very useful for tourism entrepreneurs, for local and central public authorities and the conclusions and recommendations extracted from the questionnaires can suggest valuable ideas for the relaunch and development of tourism in the Danube Delta. 


\section{Review of the scientific literature}

Used in disciplines such as psychology, ecology or engineering, resilience is a term that, in recent years, is increasingly used in connection with the success of an organization. Organizational resilience can be defined as the ability to recover or adapt quickly to adverse situations or changes. Whatever definition or term we adopt, after numerous corporate scandals and a financial crisis that has shaken the entire globe, it is considered that a successful organization must be able to withstand shocks, remain as strong as a result of these shocks, adapt to change and even more, take advantage of the opportunities that any change brings. But how can an organization gain resilience? A well-known theory published in 2011 by a well-known UK association, AIRMIC (Association of Risk and Insurance Managers in Industry and Commerce), is the theory of the 5 Rs: Risk Radar, Resources, Organization Relations, Rapid Incident Response, and Reviewing and adapting the organizational environment (Gössling, Scott and Hall, 2020). Some specialists in the field of organizational resilience wonder if we are not wrong when we consider that the state of normalcy is represented by stability and maintaining the status quo. If we considered that normalcy means permanent change and adaptation, and a period of stability would be just an accident, a short period of time that we must not be deceived? Perhaps this approach is indeed the secret of a resilient organization. The tourism industry has evolved rapidly in recent decades. In addition to the positive effects of generating growth in the destination areas, there are also negative effects with an impact on areas such as the environment, culture, politics, social and economic (Duțescu, Popa and Ponorîcă, 2014). The new policy framework for European tourism, adopted by the Commission in 2012, includes the promotion of sustainable, responsible and quality tourism. The key issues involve limiting the environmental impact of transport related to tourism, as well as limiting the negative impact on tourist destinations (Țală and State, 2020). The growing need for sustainability is also a result of the high volume of knowledge and concern about the impact on tourism and environmental issues in general. The development of tourism without sustainability can lead to serious deterioration of society, but also of the environment and the entire tourism industry. Tourism activities have repercussions on the economy, on the natural environment and on the local population of the destination (Glaser-Segura, Nistoreanu and Dincă, 2018.). Tourism activities generates multiple impacts, the range and variety of production factors needed to produce these goods and services purchased by visitors and the range of agents interested or affected by tourism, it is necessary to adopt an integrated approach to tourism development, management and control (Amicarelli, et al., 2020). This approach is recommended for the formulation and implementation of national and local tourism policies, as well as the necessary international agreements or other mechanisms on tourism (Nistoreanu and Hadad, 2020).

\section{Research methodology}

This research focuses on two main aspects, each equally important for tourism actors. First, we analyzed the impact of the Covid-19 pandemic on tourism in the Danube Delta in 2020 and whether the resilience and sustainability test was passed. The second aim of the research was to identify solutions for the relaunch and development of tourism in the Danube Delta. Several research methods have been used to meet our objectives, such as analysis, synthesis, comparison, observation or documentary research. The quantitative research methodology used is limited to the questionnaire-based survey. The questionnaire contained 16 questions and was administered online between 10-25 March 2021. We had a number of 35 respondents, owners or administrators of classified accommodation units in the Danube Delta. In order to have a more accurate picture about the impact of the Covid-19 pandemic on tourism in the Danube Delta, we asked questions to tourism entrepreneurs in localities that cover almost the entire Danube Delta: Crişan, Mila 23, Caraorman, Letea, Somova, Sfântu Gheorghe, Chilia, Dunavăţ, Murighiol, Sulina, Maliuc, Gorgova.

\section{Results and discussion}

The questionnaire was administered online between 10-25 March 2021. This study was answered by 35 owners or administrators of classified accommodation units in the Danube Delta. When asked about the impact of the pandemic on tourism in the Danube Delta, $69 \%$ of respondents believe that the impact was positive or neutral and only $31 \%$ believe that the impact was negative. The figures are spectacular, if we make a comparison with the huge negative effects produced at the level of world and national tourism by the pandemic -Figure no. 1. 
2. What was the impact of the COVID-19

Pandemic on tourism in the Danube Delta?

35 answers

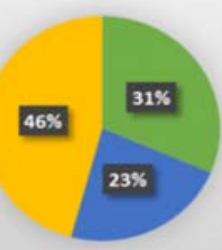

wegative

neutral

in Positive

Figure no. 1. The impact of the COVID-19 Pandemic on tourism in Danube Delta Source: Own processing of the data from the questionnaire

The same neutral to positive aspect emerges from the answers related to the impact of the pandemic on tourism in the Danube Delta, when we talk about tourism businesses, affected jobs or closure - Figure no. 2, 3 and Table no. 3 .

\section{What was the impact of the COVID-19}

Pandemic on your business?

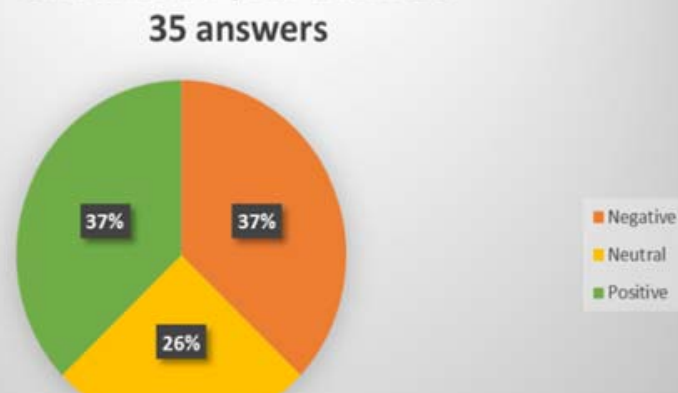

Figure no. 2. The impact of the COVID-19 Pandemic on business Source: Own processing of the data from the questionnaire

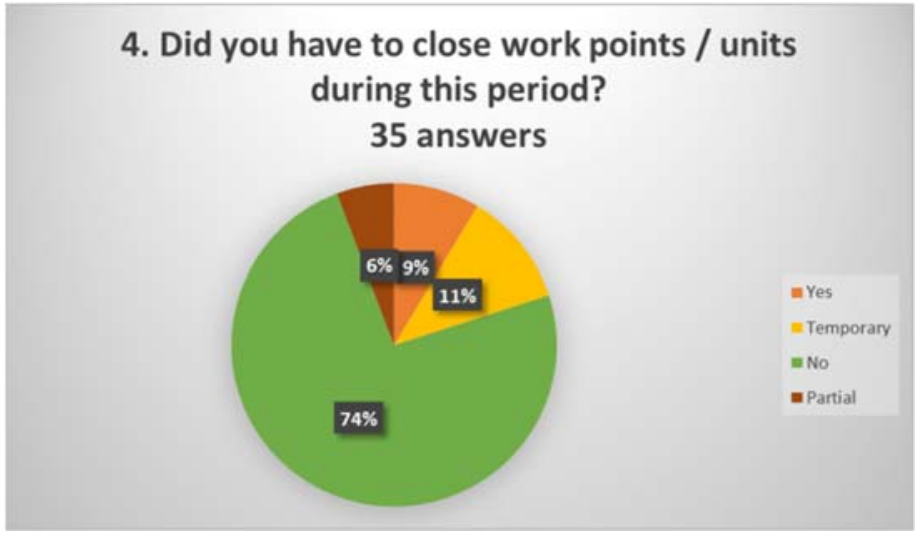

Figure no. 3. The impact of the COVID-19 Pandemic on tourism Source: Own processing of the data from the questionnaire 
Table no. 3. Questionnaire on the impact of the COVID-19 Pandemic on tourism in Danube

\begin{tabular}{|c|c|c|}
\hline \multicolumn{3}{|r|}{ Delta } \\
\hline Nr. & QUESTIONNAIRE QUESTIONS & ANSWER VARIANTS / ANSWERS \\
\hline 1 & $\begin{array}{l}\text { What was the impact of the COVID-19 } \\
\text { Pandemic on tourism in Romania? }\end{array}$ & $\begin{array}{l}\text { Negative }-97 \% \\
\text { Neutral }-3 \% \\
\text { Positive }-0 \%\end{array}$ \\
\hline 2 & $\begin{array}{l}\text { What was the impact of the COVID-19 } \\
\text { Pandemic on tourism in Danube } \\
\text { Delta? }\end{array}$ & $\begin{array}{l}\text { Negative }-31 \% \\
\text { Neutral }-23 \% \\
\text { Positive }-46 \% \\
\end{array}$ \\
\hline 3 & $\begin{array}{l}\text { What was de impact of the COVID-19 } \\
\text { Pandemic on your business? }\end{array}$ & $\begin{array}{l}\text { Negative }-37 \% \\
\text { Neutral }-26 \% \\
\text { Positive }-37 \% \\
\end{array}$ \\
\hline 4 & $\begin{array}{l}\text { Did you have to close work } \\
\text { points/units during this period? }\end{array}$ & $\begin{array}{l}\text { Yes }-9 \% \\
\text { Temporary - } 11 \% \\
\text { No }-74 \% \\
\text { Partial }-6 \%\end{array}$ \\
\hline 5 & $\begin{array}{l}\text { Did you have to lay off staff during this } \\
\text { period? }\end{array}$ & $\begin{array}{l}\text { Yes }-11 \% \\
\text { Temporary-20\% } \\
\text { No }-66 \% \\
\text { Partial }-3 \%\end{array}$ \\
\hline 6 & $\begin{array}{l}\text { What losses did you have or estimate } \\
\text { you will have? }\end{array}$ & $\begin{array}{l}\text { Very big }-23 \% \\
\text { Big }-14 \% \\
\text { Minimal }-17 \% \\
\text { Nothing }-46 \% \\
\end{array}$ \\
\hline 7 & $\begin{array}{l}\text { In this crisis, the Government's assis- } \\
\text { tance was: }\end{array}$ & $\begin{array}{l}\text { Big - } 0 \% \\
\text { Small }-43 \% \\
\text { Medium - 6\% } \\
\text { Nothing }-51 \%\end{array}$ \\
\hline 8 & $\begin{array}{l}\text { In this crisis, the help from the local } \\
\text { authorities was: }\end{array}$ & $\begin{array}{l}\text { Big - } 0 \% \\
\text { Small - 0\% } \\
\text { Medium - 49\% } \\
\text { Nothing - 51\% }\end{array}$ \\
\hline 9 & $\begin{array}{l}\text { What steps would you like the govern- } \\
\text { ment and state institutions working in } \\
\text { the field of tourism to take to help you } \\
\text { overcome the pandemic crisis? }\end{array}$ & $\begin{array}{l}\text { State funds }-29 \% \\
\text { Guaranteed/subsidized loans }-6 \% \\
\text { Exemptions or postponements of taxes } \\
\text { and duties }-31 \% \\
\text { Insistent promotion of the Danube Delta }-34 \%\end{array}$ \\
\hline 10 & $\begin{array}{l}\text { What steps do you take to minimize } \\
\text { the impact of Covid-19 on your com- } \\
\text { pany's business strategy, sales and } \\
\text { cash flow? }\end{array}$ & $\begin{array}{l}\text { Reduction of staff }-3 \% \\
\text { Loans }-6 \% \\
\text { Adding other services for tourists - 30\% } \\
\text { Sale of certain products obtained locally-24\% } \\
\text { Promoting offers in agencies in other countries - 19\% } \\
\text { Aggressive promotion - } 18 \%\end{array}$ \\
\hline 11 & $\begin{array}{l}\text { When do you expect a stabilization of } \\
\text { the Romanian tourism industry? }\end{array}$ & $\begin{array}{l}2021-5 \% \\
2022-60 \% \\
2023-32 \% \\
2024-3 \%\end{array}$ \\
\hline 12 & $\begin{array}{l}\text { When do you expect a stabilization of } \\
\text { the tourism industry in the Danube } \\
\text { Delta? }\end{array}$ & $\begin{array}{l}2021-40 \% \\
2022-32 \% \\
2023-28 \% \\
2024-0 \% \\
\end{array}$ \\
\hline 13 & $\begin{array}{l}\text { Did Romanian tourists choose the } \\
\text { Danube Delta as a tourist destination } \\
\text { in } 2020 \text {, because they had the oppor- } \\
\text { tunity to use holiday vouchers? }\end{array}$ & $\begin{array}{l}\text { Majority - } 26 \% \\
\text { Small majority - } 46 \% \\
\text { They came anyway, even on their own money }-28 \%\end{array}$ \\
\hline 14 & $\begin{array}{l}\text { Tourists have chosen the Danube } \\
\text { Delta as a tourist destination in 2020: }\end{array}$ & $\begin{array}{l}\text { Because they are passionate about the wild }-9 \% \\
\text { To know the local culture and traditions }-14 \%\end{array}$ \\
\hline
\end{tabular}




\begin{tabular}{|c|c|c|}
\hline \multicolumn{3}{|c|}{ New Trends in Sustainable Business and Consumption } \\
\hline & & $\begin{array}{l}\text { To protect yourself from Covid- } 19-71 \% \\
\text { For the local gastronomic offer }-6 \%\end{array}$ \\
\hline 15 & $\begin{array}{l}\text { Tourists who visited the Danube Delta } \\
\text { in } 2020 \text { preferred accommodation in } \\
\text { the reception structures: }\end{array}$ & $\begin{array}{l}\text { Maximum } 8 \text { rooms }-63 \% \\
\text { Between } 9 \text { and } 15 \text { rooms }-23 \% \\
\text { Up to } 15 \text { rooms }-14 \%\end{array}$ \\
\hline 16 & $\begin{array}{l}\text { For the development of tourism in the } \\
\text { Danube Delta, the authorities must: }\end{array}$ & $\begin{array}{l}\text { Develop transport infrastructure }-23 \% \\
\text { Promote more aggressively the Danube Delta - } 25 \% \\
\text { Organize several events - } 26 \% \\
\text { Grants tax exemptions to classified accommodation } \\
\text { ownners }-26 \%\end{array}$ \\
\hline
\end{tabular}

Source: Own processing of the data from the questionnaire

\section{Conclusions}

From the on-site analysis, from the interpretation of the data in the questionnaire, as well as from the comparative analysis with other tourist areas in Romania, it results that the pandemic had a neutral to positive effect for tourism in the Danube Delta and that, for the most part, the resilience and sustainability has been passed. In 2020, tourists were looking for safe, secluded destinations with smaller accommodation units, and the Danube Delta came first. From the findings made last summer on the spot, official statistics do not provide an accurate picture of the actual number of tourists who visited the delta. Many Romanian tourists stayed at unclassified guesthouses, locals or tents. There were periods from July to August, when the boat traffic on the canals of the Danube Delta was very crowded. Another aspect concerns the traditional fish meals. We must mention that many units had to offer meals from aquaculture fish, brought from Bulgaria or other countries, because the fishermen in the delta could not offer for sale the quantities requested by tourists. At this level, the balance between nature's supply and tourist demand was very fragile. Another aspect found during this period was that the aid promised by the central and local public authorities was very small, sometimes non-existent. Regarding the proposals from those who have invested in the Danube Delta, we must say that very few hope for state aid and believe that the development of transport infrastructure, intensive promotion of the delta and the organization of festivals will lead to attract more of tourists. Other accommodation units have intensified their links with travel agencies abroad, in order to attract ecotourists and lovers of traditions and gastronomy from European countries, but also from Israel, USA, Australia and Japan. We consider that this study is very useful for tourism entrepreneurs, for local and central public authorities and the conclusions and recommendations extracted from the questionnaires can suggest valuable ideas for the relaunch and development of tourism in the Danube Delta.

\section{References}

Amicarelli, V., Avram, A.C., Bux, C., Lagioia, G. and Pamfilie, R., 2020. Food Waste in the Hospitality Industry in Italian and Romanian Experience. In: R. Pamfilie, V. Dinu, L. Tăchiciu, D. Pleșea, C. Vasiliu eds. 6th BASIQ International Conference on New Trends in Sustainable Business and Consumption. Messina, Italy, 4-6 June 2020. Bucharest: ASE, pp. 1012-1019.

Brouder, P., 2020. Reset redux: possible evolutionary pathways towards the transformation of tourism in a COVID-19 world. Tourism Geographies, 22(3), pp.484-490.

Duţescu, A., Popa, A.F., Ponorîcă, A.G., 2014. Sustenabilitatea în industria turismului, bazată pe indicatorii cheie de performanţă, Abordări contemporane și provocări ale turismului durabil. Amfieatru Economic, 16(special issue 8), pp.830-831.

Glaser-Segura, D., Nistoreanu, P. and Dincă, V.M., 2018. Considerations on Becoming a World Heritage Site - A Quantitative Approach. Amfiteatru Economic, 20(47), pp.202-216.

Gössling, S., Scott, D. and Hall, C.M., 2020. Pandemics, tourism and global change: a rapid assessment of COVID-19. Journal of Sustainable Tourism, 29(1), pp.1-20.

Nistoreanu, P. and Hadad, S., 2020. Tourism - History, Statistics and Reality. In: R. Pamfilie, V. Dinu, L. Tăchiciu, D. Pleșea, C. Vasiliu eds. 6th BASIQ International Conference on New Trends in 
Sustainable Business and Consumption. Messina, Italy, 4-6 June 2020. Bucharest: ASE, pp.11331139.

Volkmann, C., Tokarski, K.O., Dincă, V.M and Bogdan, A., 2021. The Impact of COVID-19 on Romanian Tourism. An Explorative Case Study on Prahova County, Romania. Amfiteatru Economic, 23(56), pp. 196-205

Sârbu, R., Ciobanu, G., Popescu, M.L. and Troacă, V.A., 2020. The Impact of Digitization on the Labor Market Paths and Development Opportunities. In: R. Pamfilie, V. Dinu, L. Tăchiciu, D. Pleșea, C. Vasiliu eds. 6th BASIQ International Conference on New Trends in Sustainable Business and Consumption. Messina, Italy, 4-6 June 2020. Bucharest: ASE, pp. 214-221.

Țală, M.L. and State, O., 2020. Managerial Current Issues in the Context of Organizational Behaviour in Tourism. In: R. Pamfilie, V. Dinu, L. Tăchiciu, D. Pleșea, C. Vasiliu eds. 6th BASIQ International Conference on New Trends in Sustainable Business and Consumption. Messina, Italy, 4-6 June 2020. Bucharest: ASE, pp. 411-418. 